\title{
Analysis of Managing Creativity for Entrepreneurs
}

\author{
Ati Cahayani \\ Atma Jaya Catholic University, Jakarta, Indonesia
}

\begin{abstract}
In Indonesia, open unemployment until August 2011 was 7,700,086. Although this number has decreased compared with the number of unemployed in February 2011, which is $8,117,631$, but the decline is not very significant. Unemployment occurs because labor forces are not absorbed into employment. One way to reduce unemployment is to open their own employment or become entrepreneurs. In fact, the government of Indonesia has made some efforts to the growth of new entrepreneurs, for example, by providing funding for student entrepreneurship program to a number of universities in Indonesia. However, efforts by the government are useless if there is no intention in the individual itself, and there are five factors driving intention in entrepreneurship, which invest, creativity, market opportunity, autonomy, status. Meanwhile, some researchers have conducted research about factor which driving the entrepreneurial intention. The result of that research shows that the most encouraging factor is the creativity. However, creativity must be managed properly in order to give optimal results. This article wants to analyze the management of creativity among entrepreneurs in order to give optimal results. The research was conducted among young entrepreneurs, which are still a college student or had graduated from college. The total informants for this research are five informants from three private universities/colleges. This research used interview to collect data. This study attempted to process qualitative data obtained from interviews with young entrepreneurs. The result of this research is all of the respondents use some techniques to maintain and enhance creativity, such as "allow you to creative", "think out of the box", and "be persistent”. From the findings of this study, it also can be seen that the young entrepreneurs are able to overcome the barriers to creativity, "believing that I am not creative”.
\end{abstract}

Keywords: managing and enhancing creativity, entrepreneurs, barriers to creativity

\section{Introduction}

In Indonesia, open unemployment until August 2011 was 7,700,086 (Biro Pusat Statistik, 2012). Although this number has decreased compared with the number of open unemployment in February 2011, which is $8,117,631$, the decline is not very significant. That data can be seen in Table 1 .

Meanwhile, from Table 1 we can also see that on August 2011, there are 492,343 open unemployment from bachelor degree (Biro Pusat Statistik, 2012). The number of this open unemployment is greater than the number of open unemployment from diploma on August 2011 amounted to 244,687 people (Biro Pusat Statistik, 2012).

Ati Cahayani, Doctor of Education Management, Department of Business Administration, Faculty of Business Administration and Communication Sciences, Atma Jaya Catholic University.

Correspondence concerning this article should be addressed to Ati Cahayani, Jl. Jenderal Sudirman Kav 51, Jakarta Selatan, Jakarta, 12930, Indonesia. E-mail: aticahayani@yahoo.com; ati.cahayani@atmajaya.ac.id. 
That condition indicates that graduators from diploma are more easily absorbed in the workforce rather than people with bachelor degree.

Table 1

Open Unemployment of Bachelor Degree and Diploma (Year of 2004-2011)

\begin{tabular}{|c|c|c|}
\hline Year & Diploma & Bachelor degree \\
\hline 2004 & 237.251 & 348.107 \\
\hline 2005 (Feb.) & 322.836 & 385.418 \\
\hline 2005 (Nov.) & 308.522 & 395.538 \\
\hline 2006 (Feb.) & 297.185 & 375.601 \\
\hline 2006 (August) & 278.074 & 395.554 \\
\hline 2007 (Feb.) & 330.316 & 409.890 \\
\hline 2007 (August) & 397.191 & 566.588 \\
\hline 2008 (Feb.) & 519.867 & 626.202 \\
\hline 2008 (August) & 362.683 & 598.318 \\
\hline 2009 (Feb.) & 486.399 & 626.621 \\
\hline 2009 (August) & 441.100 & 701.651 \\
\hline 2010 (Feb.) & 538.186 & 820.020 \\
\hline 2010 (August) & 443.222 & 710.128 \\
\hline 2011 (Feb.) & 434.457 & 612.717 \\
\hline 2011 (August) & 244.687 & 492.343 \\
\hline
\end{tabular}

http://www.bps.go.id/tab_sub/view.php?kat=1\&tabel=1\&daftar=1\&id_subyek=06\&notab=4.

One way to reduce unemployment is by have business or turn into entrepreneurs. In fact, Ministry of Education and Culture of Indonesia since 2009 has launched the Student Entrepreneurial Program (PMW). The program is intended to provide sufficient knowledge, skills, and entrepreneurial spirit based on science and technology to students in order to become strong and successful entrepreneur in the face of global competition (Ministry of Education and Culture of Indonesia, 2012).

However, efforts by the government are useless if there is no intention in the individual itself to run the business. Because, entrepreneurial intention is a significant initiative factor in the entrepreneurial process (Lo \& Wang, 2007, pp. 21-43). According to Volery, Does, and Mazzarol (1997), there are five factors driving the entrepreneurial intention, which invest, creativity, market opportunity, autonomy, status. Meanwhile, Surya and Cahayani (2012) have conducted research about factor which driving the intention in entrepreneurship. The result of that research shows that the most encouraging factor is the creativity, whose MOS score is 4.28 of 5 . Creativity here shows that an entrepreneur can express their creative ideas, without any limitations of the other party. Thus, the results of these studies suggest that the majority of respondents opted to become entrepreneurs because they can reveal their creativity.

But, creativity also can become barrier to start-up business. According to Robertson et al. (2003), eliminating of barriers to start-up is a key to stimulating people to start new business. Robertson et al. (2003) said one of the barriers to start-up business is lack of idea. Lack of idea has root on lack of creativity. They are some students who said that they think they cannot be good entrepreneur because they do not think that they have creativity. They said, they want to be entrepreneur but do not know how to be a creative person. And, some of them still think that creativity is a gift or divine feature. So, if they think that they have that gift, they can think or 
do something creatively.

In addition, the entrepreneurs are required to have the creativity, especially since the business world is changing very fast. Without creativity, the business cannot keep up with the times. The entrepreneur must strive so that they always have the creativity. So, creativity must be managed properly in order to give optimal results. This article wants to analyze the way to managing creativity among entrepreneurs in order to give optimal results.

This article is expected to provide new information on how to maintain and enhance creativity made by entrepreneurs, especially young entrepreneurs.

\section{Conceptualization}

Creativity is the highly ambiguous concept and gives a lot of meanings (Berglund \& Wennberg, 2006). Nicholas and Stokes (2005) said, creativity is the generation of new idea. The official definition usually contains at least these two characteristics: newness and appropriateness (Henry, 2001). From the definition, it can be seen that creativity is useless if it cannot be applied or used.

In the business context, creativity often translated into idea development, new product innovations, and adapting or improving existing innovations (Berglund \& Wennberg, 2006). From the definition above, we can say that creativity is the root of business. It can be said that "no creativity, no business". In Indonesia, McDonalds is the first fast food restaurant that gives delivery service with one phone number (14045). This service is particularly useful for consumers because consumers do not need to remember a phone number long and is different for each branch. That service came about due to creative thinking.

But, most people think that they do not have enough creativity to start new business. Scarborough (2011) said there are 10 barriers to creativity:

- Searching for the one "right";

- Focusing on "being logical”;

- Blindly following the rules;

- Constantly being practical;

- Viewing plays as frivolous;

- Becoming overly specialized;

- Avoiding ambiguity;

- Fearing looking foolish;

- Fearing mistakes and failure;

- Believing that "I'm not creative".

To overcome those barriers, Scarborough (2011) also explains some ways to managing and enhancing individual creativity:

- Allow yourself to be creative;

- Give your mind fresh input every day;

- Observe the product and services of other companies, especially those in completely different market;

- Recognize the creative power of mistake;

- Notice what is missing;

- Keep a journal handy to record your thoughts and ideas; 
- Listen to other people;

- Listen to customer;

- Talk to a child;

- Do something ordinary in an usual way;

- Keep a toy box in your office;

- Do not throw away seemingly "bad” ideas;

- Read book on stimulating creativity or take a class on creativity;

- Take some time off;

- Be persistent.

\section{Methodology}

This study used purposive sampling because the researcher only chooses respondents who are college student or alumni from some college or university who run business, at least starting one year before this research was held. Researchers selected five respondents with different businesses, which in farming of betta fish or fighting fish, cupcake and chocolate praline, product recycling, gas reseller, and traditional food.

This research attempted to process qualitative data obtained from interviews with young entrepreneurs. Researcher particularly wants to get in-depth data on how young entrepreneurs get creative, what things those lead them to creativity, and how they strive to be always creative.

\section{Data}

(1) Respondent P is alumni from Catholic University of Atma Jaya Jakarta. He is farming of betta fish or fighting fish. He started his business since five years ago, but sometimes the business stopped because he was busy with his studies. But, he did his business seriously in 2010. The idea to start business in this sector came from himself who saw a pretty good market opportunity. Although his business seems monotonous and does not require high creativity, but $P$ still think creativity is important, and he have been done some creative efforts in his business. $\mathrm{P}$ has tried to think out of the box because if the rainy season comes, the room temperature becomes unstable so many fish seeds dead. P tried to maintain the room temperature, by using a light above the seedling containers made of Styrofoam, and it works. P claim that he must tried over and over to fit the room temperature with the need of the fish seeds. $\mathrm{P}$ argues that, creativity needs to be managed by always thinking positive and thinking out of the box, and dare to try things that others often regarded as something abnormal.

(2) Respondent L is alumni from Catholic University of Atma Jaya. She has been running chocolate praline and cupcakes business since 2010. She said, at first, that she tried to make and sell chocolate praline for fundraiser in her university. After she found that she can make money from that business, she made decision to run business in this sector. Respondent $\mathrm{L}$ think that one of her strength as an entrepreneur is have a lot of idea. And, the idea needed in chocolate cupcake and praline business, especially in terms of variation of cupcake decoration and chocolate praline content and form. Respondent L said, she must always try to have idea to make her product still favored by customer and to fulfill consumer need. She is getting new ideas for those things from magazines, the Internet, the survey results to the competitor. She also needs creativity for packaging and delivering her product, primarily to maintain the quality of the cake and chocolate up into the hands of customers. According to L, the creativity of 
packaging and delivering techniques can be obtained from brainstorming with employees (especially delivery staff), talking with friends who run similar businesses, and also from the Internet to see the forms of attractive packaging.

(3) $\mathrm{M}$ is student from Indonesia Institute of Technology. Since junior high school, she already has this product recycling business. She made vas, accessories, and pencil-cases from bobbin thread. The initial idea to do business in this field emerging when she saw the cleaning service of the school near her house were making products from scrap. This business really needs creativity. She said, without creativity, she cannot produce any product at all. She said, one day, she made one of her product in a kindergarten because there are examples of cute pictures with interesting colors. M made those drawings as a source of inspiration. She also said that she can foster creativity continuously by looking into the surrounding environment because anything can be a source of inspiration. And, she says, on this day she never experienced shortage of creative thinking. But, she also said that sometimes she had tried repeatedly to make the product that accordance with what she wants and can be sold in the market.

(4) D is a student from Indonesia Institute of Technology. She started LPG (liquid petroleum gas) reseller since 1-2 years. She got idea to run this business from her friend. Her friend told her to run businesses which always have market demand. Fortunately, her parents has unused store room that she can used. In this LPG business, creativity is required in terms of marketing the product. D said, she had to think hard to sell her LPG to market so that the number of customers continues to grow. She said it is not enough to sell LPG only from store. She thinks, she has to do promotion and some other breakthrough. Therefore, she tried to think creatively. In order to offer LPG, she sends flyers to the neighborhoods and also visits food stalls or canteen around her store. She acclaim that not easy to get new customer, but she tries not to give up. She also does delivery service. She said that creativity is a science that never dies. D has a number of ways to maintain creativity. She always communicates with customer; always accept criticisms and suggestions from customer or people around her.

(5) $\mathrm{Y}$ is a student from Bina Nusantara University. Since six years ago, he runs business of traditional food from West Java, i.e., serabi (traditional pancake from West Java). He said that he was interested in making these products because he likes to hang out, and he thought why not hang out while making money. Serabi is a kind of snacks that can be varied taste. Y said, he has 64 variations of the flavor to the serabi he was selling. And, to be able to produce flavor variations, he needs creativity. He said, in order to generate creative ideas to add flavor variety, he talked with customers, with family, with friends, and with other merchants near his stall. He said, one of his reason to add flavor variety is to meet with customer needs. Y also said, sometime, he got criticism from his customer about the new flavor, so he must always try to do something to fix or improve that flavor.

\section{Discussion}

As we can see from those data, we can see that there are a number of things that make people feel the need to have the creativity to business. There were two respondents who said they made the product variation due to the request of the consumer. One respondent said that he was looking for creative ideas after a lot of his seed fish died because of the unstable temperature. One respondent said she had to think creatively in marketing and promoting her products. And, one respondent said that she should think creatively in order to produce a product that he could sell.

So, it can be said that creativity is needed in a variety of ways. Of the five respondents, there were two respondents who need creativity to the diversity of the products they produce, there was one respondent who need 
creativity for products he makes and also for packaging and delivering products, and one respondent who need creativity to the production techniques of the business that he run. So, even if the business does look monotonous and its products can not be varied (such as LPG business reseller), but creativity is still needed for other aspects of business, such as in the field of product marketing. To help readers understand the explanation described above, the following is displayed in Table 2 contains a summary of those explanation.

Table 2

Aspect Business that Need Creativity

\begin{tabular}{|l|l|}
\hline Respondent & Aspect business that need creativity \\
\hline $\mathrm{P}$ & Technique to maintain room temperature \\
\hline $\mathrm{L}$ & $\begin{array}{l}\text { Variety of content for praline and variety of product decoration for cupcakes. } \\
\text { Packaging and delivering technique }\end{array}$ \\
\hline $\mathrm{M}$ and $\mathrm{Y}$ & Variety of product \\
\hline $\mathrm{D}$ & Technique to selling and promoting the LPG \\
\hline
\end{tabular}

All of those respondents always trying to manage the creativity required in business by doing some ways that can lead to creative business ideas. For ease of the reader, the following display tables to describe efforts to manage creativity to help readers understand the explanation described above, the following is displayed in Table 3 contains a summary of those explanation.

Table 3

Activity to Managing and Enhancing Creativity

\begin{tabular}{|c|c|c|}
\hline Respondent & Activity to managing and enhancing creativity & $\begin{array}{l}\text { Activity to managing and enhancing creativity } \\
\text { according Scarborough }\end{array}$ \\
\hline $\mathrm{P}$ & $\begin{array}{l}\text { Always thinking positive } \\
\text { Thinking out of the box } \\
\text { Dare to try things that others often regarded as something } \\
\text { abnormal } \\
\text { Must tried over and over to fit the room temperature with the } \\
\text { need of the fish seeds }\end{array}$ & $\begin{array}{l}\text { give your mind fresh input every day } \\
\text { allow yourself to be creative } \\
\text { be persistent }\end{array}$ \\
\hline $\mathrm{L}$ & \begin{tabular}{|l|} 
Reading magazines \\
Browsing the Internet \\
Survey results to the competitor \\
Brainstorming with employees (especially delivery staff) \\
Talking with friends who run similar businesses \\
Always try to have idea to make her product still favored by \\
customer and to fulfill consumer need
\end{tabular} & $\begin{array}{l}\text { give your mind fresh input every day } \\
\text { listen to other people } \\
\text { listen to customer } \\
\text { observe the product and services of other } \\
\text { companies, especially those in completely } \\
\text { different market } \\
\text { be persistent }\end{array}$ \\
\hline M & $\begin{array}{l}\text { Talking with somebody } \\
\text { Looking into the surrounding environment } \\
\text { Tried repeatedly to make the product that accordance with what } \\
\text { she wants and can be sold in the market }\end{array}$ & $\begin{array}{l}\text { listen to other people } \\
\text { give your mind fresh input every day } \\
\text { be persistent }\end{array}$ \\
\hline $\mathrm{D}$ & $\begin{array}{l}\text { Communicates with customer } \\
\text { Always accept criticisms and suggestions from customer or } \\
\text { people around her } \\
\text { tries not to give up }\end{array}$ & $\begin{array}{l}\text { listen to other people } \\
\text { listen to customer } \\
\text { be persistent }\end{array}$ \\
\hline $\mathrm{Y}$ & $\begin{array}{l}\text { talked with customers } \\
\text { talk with family, friends, and with other merchants near his stall } \\
\text { must always try to do something to fix or improve that flavor }\end{array}$ & $\begin{array}{l}\text { listen to other people } \\
\text { listen to customer } \\
\text { be persistent }\end{array}$ \\
\hline
\end{tabular}

From Table 3 it can be seen that majority of them use technique "listen to other people" and "listen to customer". However, this can only be done by people who are willing to humbly listen to others and to their customers. They did not think himself as the most intelligent person and not feel as the most know everything. 
People who are willing to listen to others and listen to customers (especially criticism from customers) will get a lot of knowledge, and it can open up your mind about the best idea.

Meanwhile, some respondents use technique "give your mind fresh input everyday". This can be done by a walk to look around, read a magazine, or by browsing the internet. Creative ideas can arise in a calm state of mind and by read or see something new.

But, only one respondent who use technique, "allow yourself to creative”. This respondent always tries to think "out of the box" and dare to try things that others often regarded as something abnormal. This is the most difficult thing to do because most of people think that she/he is not creative. Researchers have been met with a lot of students who can not think creatively so that after graduation they would prefer to be employees rather than entrepreneurs.

There is one interesting thing of the findings in the field. That is, all respondents using the technique "be persistent”. This is important because without determination and persistence, people will not continually try to find something new, innovative, and creative. When an entrepreneur straight up so having one failure in trying something new, he/she will not be able to sustain its business or his/her business can not grow.

\section{Resume}

From the explanation above, it can be concluded that young entrepreneurs have the ways to maintain and enhance their creativity. The respondent seeks creative thinking not only for the product but also creativity in marketing and production techniques. This is exciting because they have realized that creativity is required in all aspects of the business. So it can be said that they realized that creativity is the most important thing to their business sustainability.

However, from the above data, it can be seen that they only use a small number of techniques to maintain and enhance the creativity of the many techniques proposed by Scarborough (2011). They may need to expand the ways to still be able to think creatively, so that creative ideas could always emerge. But from some of the technique that they use, the most important technique is "be persistent". Without determination and persistence, we can do or produce something new, unique, or innovative.

From the findings of this study, it can be seen that the young entrepreneurs are able to overcome the barriers to creativity, "believing that I am not creative". They realize and believe that creative ideas can be obtained during an attempt to do that. Their business is expected to survive, and even more advanced with the creativity.

\section{References}

Berglund, H., \& Wennberg, K. (2006). Creativity among entrepreneurship students: Comparing engineering and business education. International Journal of Continuing Engineering Education and Lifelong Learning, 16(5), 366-379.

Biro Pusat Statistik (Centre Bureau of Statistic). (2012). Pengangguran terbuka menurut pendidikan tertinggi yang ditamatkan 2004, 2005, 2006, 2007, 2008, 2009, 2010, dan 2011. Retrieved August 6, 2012, from http://www.bps.go.id/tab_sub/view.php?kat=1\&tabel=1\&daftar=1\&id_subyek=06\&notab=4

Henry, J. (2001). Creativity and perception in management. London: Sage Publications.

Kementrian Pendidikan dan Kebudayaan (Ministry of Education and Culture of Indonesia). (2012). Program mahasiswa wirausaha. Retrieved October 8, 2012, from http://www.dikti.go.id/?page_id=447\&lang=id

Lo, C. M., \& Wang, J. R. (2007). The entrepreneurial intention under environmental uncertainty. Journal of Accounting, Finance \& Management Strategy, 3(1), 21-43. 
Nicholas, C. W., \& Stokes, D. (2005). Managing creativity and innovation: The challenge for cultural entrepreneurs. Journal of Small Business and Enterprise Development, 12(3), 366-378.

Robertson, M., Collins, A., Medeira, N., \& Slater, J. (2003). Barriers to start-up and their effect on aspirant entrepreneurs. Education \& Training, 45(6), 308-316.

Scarborough, N. M. (2011). Essentials of entrepreneurship and small business management (6th ed.). Upper Saddle River, NJ: Pearson.

Surya, A., \& Cahayani, A. (2012). Analysis of entrepreneurial intentionality of student in faculty of business administration and communication sciences, Atma Jaya, Catholic University. In N. Sarinastiti et al. (Eds.), Entrepreneurship in Global Competition. Jakarta: Atma Jaya University Publisher-Jakarta.

Volery, T., Does, N., \& Mazzarol, T. (1997). Triggers and barriers affecting entrepreneurial intention: The case of western Australia nascent entrepreneurs. Proceedings from 42nd ICSB World Conference, San Francisco. 